\title{
Are Pediatric Emergency Care Applied Research Network Rules (PECARN) Sufficient for Computed Cranial Tomography Decision in Pediatric Patients with Mild Head Trauma?
}

\author{
Hasan Mansur Durgun ${ }^{l}$, Erkan Tektas ${ }^{2}$, Yllmaz Zengin ${ }^{1}$, Recep Dursun ${ }^{1}$, Mustafa İçerl, Mehmet Ustundag ${ }^{3}$, \\ Murat Orak', Cahfer Guloglu
}

\begin{abstract}
Objective: In this study we aimed to investigate the applicability of Pediatric Emergency Care Applied Research Network (PECARN) rules for decision to perform computed cranial tomography (CCT) in pediatric patients with minor head trauma (MHT).

Methods: 317 pediatric patients who underwent CCT for mild head trauma were evaluated retrospectively. The patients were classified in two groups according to PECARN rules: below 2 years old, above 2 years old and then, these patient groups were classified into two subgroups according to the compatibility with PECARN rules. The patients requiring CCT according to PECARN rules were classified as PECARN compatible (PECARN +), the patients who underwent CCT without the need of CCT according to PECARN were classified as PECARN incompatible (PECARN -).
\end{abstract}

Results: Approximately $20 \%$ patients in PECARN (+) group had abnormalities leading to prolonged hospitalization and only $3.8 \%$ patients of PECARN (-) group had abnormalities. However, none of PECARN (-) group patients required follow-up longer than 48 hours in the hospital. The most common symptoms necessitate CCT in PECARN (+) group were scalp swelling, scalp hematoma and vomiting. In PECARN (-) group the most common signs were cuts in the scalp and dermal abrasions. The incidence of fracture in CCT was significantly higher in PECARN (+) group.

Conclusion: Because CCT poses serious radiation exposure, neurological examination and clinical follow-up should be preferred in the evaluation of children with MHT. In conclusion, PECARN rules were sufficient for CCT decision in pediatric patients with MHT. J Clin Exp Invest 2016; 7 (1): 35-40

Key words: Minor head trauma, pediatric trauma, computed cranial tomography

\section{Hafif Kafa Travmalı Pediyatrik Hastalarda Bilgisayarlı Beyin Tomografisi Kararı Için PECARN Kuralları Yeterli midir?}

\section{ÖZET}

Amaç: Bu çalışmadaki amacımız hafif kafa travmaları (HKT) olan pediyatrik hastalarda Pediatric Emergency Care Applied Research Network (PECARN) kurallarının bilgisayarlı beyin tomografisi (BBT) gereksinimi konusunda uygulanabilirliğini araştırmaktır.

Yöntemler: Bu çalışmada hafif kafa travması ile acile başvuran ve BBT çekilen 317 pediyatrik hasta retrospektif olarak incelenmiştir. Hastalar önce PECARN kuralları gereği iki yaş altı ve iki2 yaş üstü olarak iki gruba ayrıldı; daha sonra bu hasta grupları PECARN kurallarına uyuma göre iki gruba ayrıldı. PECARN kurallarına göre BBT çekilmesi gerekenler PECARN uyumlu (PECARN +) ve gerekmeyip BBT çekilmiş olanlar PECARN uyumsuz (PECARN -) olarak gruplandırıldı.

Bulgular: BBT sonuçlarına göre incelendiğinde PECARN (+) grubun yaklaşık \%20'sinde hastanede yatış süresini arttıran çeşitli patolojiler görülürken PECARN (-) grubun sadece \%3,8'inde patoloji görülmüş olup hiçbirinde hastanede 48 saatten fazla takip ihtiyacı olmadı. PECARN (+) grupta BBT çekimini gerektiren en sık görülen bulgular, skalp şişliği veya hematomu ve kusma idi. PECARN (-) grupta en sık görülen bulgular çeşitli büyüklükte skalp kesileri ve dermal abrazyonlar idi. BBT'de fraktür görülmesi PECARN (+) grupta anlamlı derecede yüksek bulundu.

Sonuç: BBT ile ciddi radyasyon maruziyeti söz konusu olduğu için minör kafa travmalı çocukların değerlendirilme ve takiplerinde öncelikle nörolojik muayene ve klinik izleme önem verilmesi gerekir. Sonuç olarak, HKT'lı pediyatrik hastalarda BBT kararı için PECARN kuralları yeterlidir.

Anahtar kelimeler: Hafif kafa travması, pediyatrik travma, bilgisayarlı beyin tomografisi

${ }^{1}$ Emergency Medicine Department, Medical Faculty of Dicle University, Diyarbakir, Turkey

${ }^{2}$ Emergency Medicine Department, Gazi Yaşargil Training Research Hospital, Diyarbakir, Turkey

${ }^{3}$ Emergency Medicine Department, Medical Faculty of Dicle University, Diyarbakir, Turkey

${ }^{4}$ Emergency Medicine Department, Medical Faculty of Dicle University, Diyarbakir, Turkey

Correspondence: Hasan Mansur Durgun,

Emergency Medicine Department, Medical Faculty of Dicle University, Diyarbakir, Turkey Email: hmdurgun@gmail.com

Received: 01.02.2016, Accepted: 17.03.2016

Copyright (C) JCEI / Journal of Clinical and Experimental Investigations 2016, All rights reserved 


\section{INTRODUCTION}

Head trauma is one of the most common reasons for pediatric emergency. Minor head trauma accounts for the majority of these cases. There are many differences between childhood and adulthood head traumas. Children are more susceptible because they have a larger head to body size ratio, thinner cranial bones providing less protection to the intracranial contents, different injury mechanism and long-term prognosis compared to adults $[1,2]$. Therefore, head traumas in this age group should be differentiated from adults, and evaluated separately. Head traumas are classified according to Glasgow Coma Scale (GCS) as mild, moderate and severe head traumas. The patients with GCS 14-15 are classified as mild head trauma (MHT), GCS $9-13$ as moderate head trauma and GCS $3-8$ as severe head trauma. In moderate and severe head trauma, general approach is computed cranial tomography (CCT). However, it is controversial to determine the MHT patients that should undergo CCT. Mild head trauma should never be considered as simple head trauma. It is important to determine the CCT time in this group [3]. On one hand, there is a risk of serious brain event, even the patient has the signs of MHT, and on the other hand, CCT is potentially hazardous especially in the pediatric age group.

The diagnosis and exclusion of possible brain injuries in MHT patients does not have any clear criteria yet. Given the frequency of minor head traumas in the children and the risk of radiation exposure due to CCT; clinical follow-up and neurological examination are the preferred first-line approaches instead of the advanced imaging methods. Following the neurological examination and clinical follow-up, the doctors determine whether CCT is required. Although noncontrast CCT is the ideal imaging method for head traumas, the long-term hazardous complications should be considered. Besides, there is a cancer risk due to radiation in 1 of 2000 children who underwent CCT [4,5]. Brenner et al declared that the life-threatening cancer risk including brain tumor and leukemia may increase even with single BT in the children. In addition, exposure of low-dose ionized radiation in the brain during infancy may affect cognitive abilities in the adulthood. This risk is low individually, however, may be an important public health issue as compared to the general population [6].

In 2009, PECARN (Pediatric Emergency Care Applied Research Network) [7] performed a multicenter, large study and the investigators attempted to identify and evaluate a prediction rule for the pediatric MHT patients who were at low risk for clinically significant intracranial hemorrhage, and did not require CCT. Two prediction rules were determined to evaluate the validity in all pediatric age groups: before two years old, after two years old.

In our clinic, CCT is decided according to neurological examination and clinical follow-up independent of PECARN rules. In this study, we searched answers for 2 questions. Firstly, would the number of the patients underwent CCT be lower if we had followed the PECARN rules in the patients underwent CCT independent of PECARN rules? Secondly, would there be any unidentified severe cranial event if we had applied PECARN rules?

\section{METHODS}

In this study, the emergency registries and files of 0-15 year-old pediatric patients admitted to Dicle University Medical Faculty Hospital Emergency Department with a head trauma between 1 January 2012 and 31 December 2013 were retrospectively screened. The clinical and demographical features, radiographical assays (CCT images) and the findings of the cases were also evaluated.

Six-hundred patients were included in the study in the 2 years period. The exclusion criteria: the patients with additional organ injuries, major trauma, GCS < 14 , severe mechanism causing injury (car crash leading to jumping out, rollover or death of the passenger, car hitting to a pedestrian or a bicycler without a head guard etc..), abnormal mental health, comorbid disease in the history, and the patients without CCT. The 317 cases who had undergone CCT for mild head trauma were evaluated. The patients were classified in 2 groups according to PECARN rules: below 2 years old, above 2 years old. Then, these patient groups were classified into 2 groups according to the compatibility with PECARN rules. The patients requiring CCT according to PECARN rules were classified as PECARN compatible (PECARN +), the patients who underwent CCT without the need of CCT according to PECARN were classified as PECARN incompatible (PECARN-).

\section{Statistical analysis}

The results were presented as mean plus minus Standard deviation in the statistical analyses. Univarite statistical analyses were performed by using chi-square test for categorical variables and Student's t test for continuous variables. $\mathrm{p}<0.05$ value was considered as statistically significant. 


\section{RESULTS}

\section{Clinical and demographical features}

Total of 317 patients were included in the study: 201 males, 116 females. The mean age of the patients was: in PECARN $(+)$ group $49.6 \pm 41.7$ (month; mean $\pm \mathrm{SD}$ ), in PECARN (-) group $61.4 \pm 40.9$ (month; mean \pm SD). PECARN $(+)$ group consisted 150 males $(63.3 \%), 87$ females 87 (36.7\%), PECARN (-) group consisted 51 males (63.7\%), 29 females 29 (36.2\%). No differences in ratios of the males and females were found between groups. The comparisons by trauma types, clinical symptoms and CCT results between PECARN $(+)$ and PECARN (-) groups were summarized in table I. In these groups, the most common etiology for traumas was simple falls. The most common symptoms in PECARN (+) group were head swelling and vomiting; in PECARN (-) group head cut and dermal abrasions. When evaluated according to CCT results, $20 \%$ patients in PECARN $(+)$ group had pathologies leading to prolonged hospitalization and only $3.8 \%$ patients of PECARN (-) group had some pathologies. None of PECARN (-) group patients required follow-up longer than 48 hours in the hospital (Table 1).

\section{Clinical and demographical features of the patients below two years old}

The comparisons by demographical features, trauma types, clinical symptoms during admission and CCT results in the $<2$ years old patients between PECARN $(+)$ and PECARN (-) groups were summarized in table II. The most common etiologies for traumas were simple falls in and falls from high places in the PECARN $(+)$ patients below two years old, and simple falls in all PECARN (-)group. The most common symptoms in PECARN $(+)$ group were head swelling and vomiting; in PECARN (-) group head cut and dermal abrasion. When evaluated according to CCT results, $16 \%$ patients in PECARN (+) group had pathological CCT findings, and $10 \%$ patients' hospitalization period was longer than 48 hours, However in PECARN (-) group, none of the patients had CCT pathology, and required follow-up longer than 48 hours in the hospital (Table 2).

\section{Clinical and demographical features of the patients over two years old}

The comparisons by demographical features, trauma types, symptoms during admission and CCT results in the $>2$ years old patients between PECARN $(+)$ and PECARN (-) groups were summarized in table III.
The most common etiologies for traumas were simple falls in and falls from high places in the PECARN $(+)$ patients below two years old, and simple falls in all PECARN (-) group. The most common symptoms in PECARN (+) group were head swelling, cut and vomiting; in PECARN (-) group head cut and dermal abrasion. When evaluated according to CCT results, 23\% patients in PECARN $(+)$ group had pathological CCT findings, and $13 \%$ patients' hospitalization period was longer than 48 hours. However in PECARN (-) group, $4.30 \%$ of the patients had fractures in CCT, but none of them required follow-up longer than 48 hours in the hospital (Table 3).

Table 1. Clinical and demographical features of the patients

\begin{tabular}{|c|c|c|c|}
\hline & $\begin{array}{c}\text { PECARN (+) } \\
(\mathrm{n}=\mathbf{2 3 7}) \\
\mathrm{n}(\%)\end{array}$ & $\begin{array}{c}\text { PECARN (-) } \\
(n=80) \\
n(\%)\end{array}$ & $\mathbf{p}$ \\
\hline Age (month, mean \pm SD) & $49.6 \pm 41.7$ & $61.4 \pm 40.9$ & 0.028 \\
\hline \multicolumn{4}{|l|}{ Gender } \\
\hline Male & $150(63.3)$ & $51(63.7)$ & 1.000 \\
\hline Female & $87(36.7)$ & $29(36.2)$ & 1.000 \\
\hline \multicolumn{4}{|l|}{ Trauma type } \\
\hline Simple fall & $157(66.2)$ & $80(100)$ & $<0.001$ \\
\hline Car accident & $1(0.4)$ & 0 & 1.000 \\
\hline Fall from high & $48(20.3)$ & 0 & $<0.001$ \\
\hline Fall from stairs & $15(6.3)$ & 0 & 0.015 \\
\hline Sport injury & $1(0.4)$ & 0 & 1.000 \\
\hline Severe trauma & $8(3.4)$ & 0 & 0.209 \\
\hline \multicolumn{4}{|l|}{ Symptoms } \\
\hline Headache & $20(8.4)$ & 0 & 0.003 \\
\hline Swelling & $118(49.8)$ & 0 & 0.001 \\
\hline Cut & $38(16)$ & $54(67.5)$ & 0.001 \\
\hline Vomiting & 90 (37.9) & 0 & 0.001 \\
\hline Amnesia & $9(3.8)$ & 0 & 0.118 \\
\hline Abrasion & $28(11.8)$ & $16(20)$ & 0.091 \\
\hline \multicolumn{4}{|l|}{$\mathrm{CT}$ result } \\
\hline Normal & $191(80.6)$ & 77 (96.2) & 0.001 \\
\hline Subarachnoid $\mathrm{H}$. & $3(1.3)$ & 0 & 0.975 \\
\hline Edema & $5(2.1)$ & 0 & 0.335 \\
\hline Fracture & 40 (16.9) & $3(3.8)$ & 0.002 \\
\hline \multicolumn{4}{|l|}{ Hospitalization period } \\
\hline$\leq 48$ hours & $208(87.8)$ & $80(100)$ & $<0.001$ \\
\hline$>48$ hours & $29(12.2)$ & 0 & $<0.001$ \\
\hline
\end{tabular}

PECARN: Pediatric emergency care applied research network, $\mathrm{H}$ : Hemorrhage, CT: Computerized tomography 
Table 2. Clinical and demographical features of the patients below two years old

\begin{tabular}{|c|c|c|c|}
\hline & $\begin{array}{c}\text { PECARN (+) } \\
(n=84) \\
n(\%)\end{array}$ & $\begin{array}{c}\text { PECARN (-) } \\
(n=10) \\
n(\%)\end{array}$ & $\mathbf{p}$ \\
\hline Age & $10.39 \pm 3.06$ & $12.00 \pm 0.01$ & $<0.001$ \\
\hline \multicolumn{4}{|l|}{ Gender } \\
\hline Male & $56(66.7)$ & $4(40)$ & \multirow{2}{*}{0.161} \\
\hline Female & $28(33.3)$ & $6(60)$ & \\
\hline \multicolumn{4}{|l|}{ Trauma type } \\
\hline Simple fall & $64(76.2)$ & $10(100)$ & 0.113 \\
\hline Fall from high & $17(20.2)$ & $0(0.00)$ & 0.199 \\
\hline Fall from stairs & $2(2.4)$ & $0(0.00)$ & 1.000 \\
\hline Severe trauma & $1(1.2)$ & $0(0.00)$ & 1.000 \\
\hline \multicolumn{4}{|l|}{ Symptoms } \\
\hline Swelling & $41(48.8)$ & $0(0.00)$ & 0.004 \\
\hline Cut & $5(6.0)$ & $3(30.0)$ & 0.037 \\
\hline Vomiting & $39(46.4)$ & $0(0.00)$ & 0.005 \\
\hline Amnesia & $4(4.8)$ & $0 .(0.00)$ & 1.000 \\
\hline Abrasion & $9(10.7)$ & $4(40.0)$ & 0.030 \\
\hline \multicolumn{4}{|l|}{ CT result } \\
\hline Normal & $3(3.6)$ & $0 .(0.00)$ & 1.000 \\
\hline S. hemorrhage & $1(1.2)$ & $0(0.00)$ & 1.000 \\
\hline Edema & 10 (11.9) & $0(0.00)$ & 0.593 \\
\hline Fracture & $72(85.7)$ & $10(100.0)$ & 0.351 \\
\hline \multicolumn{4}{|c|}{ Hospitalization period } \\
\hline$\leq 48$ hours & $74(88.1)$ & $10(100.0)$ & \multirow{2}{*}{0.593} \\
\hline$>48$ hours & 10 (11.9) & $0(0.00)$ & \\
\hline
\end{tabular}

PECARN: Pediatric emergency care applied research network, $\mathrm{S}$ : Subarachnoid, CT: Computerized tomography

\section{CCT results by symptoms and trauma type in the patients over two years old}

In the patients over 2 years old, 186 patients had (83.4\%) normal CCT and 37 had (16.6\%) several pathological signs in CCT. When the effect of the symptoms on CCT results was investigated, the most common symptoms in CCT positive patients were the direct symptoms of the trauma including head swelling, cut and abrasion. The trauma types including heavy object trauma, fall from stairs, fall from a high place and bicycle accident were associated with pathological CCT results (Table 4).

\section{CCT results by symptoms and trauma type in the patients below 2 years old}

In the patients below 2 years old, 82 patients had $(87.2 \%)$ normal CCT and 12 had (12.8\%) several pathological signs in CCT. When the effect of the symptoms on CCT results was investigated, the most common symptoms in CCT positive patients were the direct symptoms of the trauma including head swelling, and abrasion. The trauma types including fall from a high place and simple falls were associated with pathological CCT results (Table 5).

Table 3. Clinical and demographical features of the patients over two years old

\begin{tabular}{|c|c|c|c|}
\hline & $\begin{array}{c}\text { PECARN (+) } \\
(n=153) \\
n(\%)\end{array}$ & $\begin{array}{c}\text { PECARN (-) } \\
(n=70) \\
n(\%)\end{array}$ & $\mathbf{p}$ \\
\hline Age & $71.1 \pm 37.2$ & $68.4 \pm 38.9$ & 0.632 \\
\hline \multicolumn{3}{|l|}{ Gender } & \multirow{3}{*}{0.456} \\
\hline Male & $94(61.4)$ & 47 (67.1) & \\
\hline Female & $59(38.6)$ & 23 (32.9) & \\
\hline \multicolumn{4}{|l|}{ Trauma type } \\
\hline Simple fall & $93(60.8)$ & 70 (100) & $<0.001$ \\
\hline Car accident & $1(0.7)$ & $0(0.00)$ & 1.000 \\
\hline Fall from high & 31 (20.3) & $0(0.00)$ & $<0.001$ \\
\hline Fall from stairs & $13(8.50)$ & $0(0.00)$ & 0.011 \\
\hline Sport injury & $8(5.20)$ & $0(0.00)$ & 0.094 \\
\hline Severe trauma & $7(4.60)$ & $0(0.00)$ & 0.101 \\
\hline \multicolumn{4}{|l|}{ Symptoms } \\
\hline Headache & $20(13.1)$ & $0(0.00)$ & 0.001 \\
\hline Swelling & 77 (50.3) & $0(0.00)$ & $<0.001$ \\
\hline Cut & $33(21.6)$ & 51 (72.9) & $<0.001$ \\
\hline Vomiting & $49(32.0)$ & $2(2.90)$ & $<0.001$ \\
\hline Amnesia & $5(3.30)$ & $0(0.00)$ & 0.328 \\
\hline Abrasion & $19(12.4)$ & 12 (17.1) & 0.405 \\
\hline \multicolumn{4}{|l|}{$\mathrm{CT}$ result } \\
\hline Normal & $4(2.60)$ & $0(0.00)$ & 0.311 \\
\hline Edema & 30 (19.6) & $3(4.30)$ & 0.002 \\
\hline Fracture & 119 (77.8) & 67 (95.7) & $<0.001$ \\
\hline \multicolumn{4}{|l|}{$\begin{array}{l}\text { Hospitalization } \\
\text { period }\end{array}$} \\
\hline$\leq 48$ hours & $134(87.6)$ & $70(100.0)$ & \multirow{2}{*}{0.001} \\
\hline$>48$ hours & $19(12.4)$ & $0(0.00)$ & \\
\hline
\end{tabular}

PECARN: Pediatric emergency care applied research network, CT: Computerized tomography 
Table 4. Cranial computerized tomography results by symptoms and trauma type in the patients over two years old

\begin{tabular}{lccc}
\hline & $\begin{array}{c}\text { CT normal } \\
(\mathbf{n}=\mathbf{1 8 6}) \\
\mathrm{n}(\%)\end{array}$ & $\begin{array}{c}\text { CT abnormal } \\
(\mathbf{n}=\mathbf{3 7}) \\
\mathrm{n}(\%)\end{array}$ & $\mathbf{p}$ \\
\hline Symptoms & $55(71.42)$ & $22(28.58)$ & 0.001 \\
\hline Swelling & $49(96.07)$ & $2(3.93)$ & 0.005 \\
\hline Vomiting & $68(80.95)$ & $16(19.05)$ & 0.462 \\
\hline Cut & $5(100)$ & $0(0.00)$ & 0.593 \\
\hline Amnesia & $25(80.64)$ & $6(19.36)$ & 0.610 \\
\hline \multicolumn{1}{|c}{ Abrasion } & $19(95)$ & $1(5)$ & 0.210 \\
\hline Headache & $150(91.46)$ & $14(8.54)$ & $<0.001$ \\
\hline Trauma type & $23(71.87)$ & $9(28.13)$ & 0.065 \\
\hline Simple fall & $5(71.42)$ & $2(28.58)$ & 0.328 \\
\hline Fall from high place & $6(46.15)$ & $7(53.85)$ & 0.002 \\
\hline Bicycle accident & $2(28.57)$ & $5(71.43)$ & 0.002 \\
\hline Fall from stairs & &
\end{tabular}

CT: Computerized tomography

Table 5. Computerized tomography results by symptoms and trauma type in the patients below two years old

\begin{tabular}{lccc}
\hline & $\begin{array}{c}\text { CT normal } \\
(\mathbf{n = 8 2}) \\
\mathrm{n}(\%)\end{array}$ & $\begin{array}{c}\text { CT abnormal } \\
(\mathbf{n = 1 2}) \\
\mathrm{n}(\%)\end{array}$ & $\mathbf{p}$ \\
\hline Symptoms & $30(68.18)$ & $11(31.82)$ & $<0.001$ \\
\hline Swelling & $39(100)$ & $0(0.00)$ & 0.001 \\
\hline Vomiting & $8(100)$ & $0(0.00)$ & 0.590 \\
\hline Cut & $13(76.47)$ & $4(23.52)$ & 0.363 \\
\hline Abrasion & & & \\
Trauma type & $67(90.54)$ & $7(9.46)$ & 0.122 \\
\hline Simple fall & $14(73.68)$ & $5(26.31)$ & 0.220 \\
\hline Fall from high place & $1(100)$ & $0(0.00)$ & 1.000 \\
\hline Heavy object trauma & & & \\
\hline
\end{tabular}

CT: Computerized tomography

\section{DISCUSSION}

Computed cranial tomography is the commonly preferred method for the patients with minor head trauma since it is superior in terms of accurate and rapid diagnosis as compared to the other methods. However, CCT is not optimal for all patients because there are lots of patients, but a few of them has intracranial pathology; besides CCT is an economical burden for the country and there is a risk of radiation exposure. Nevertheless, since the mild head trauma is not always as- sociated with a good prognosis, several studies were published and several protocols were recommended in many countries to decide whether the patient should undergo CCT or not $[1,4,8]$.

When the etiological causes of childhood head trauma were evaluated in all age groups, the falls take places on the top. Under the title of falls, there are inhouse simple falls (slipping, fall from a cradle, chair, armchair during a play), out-home simple falls (falling from stairs in school, park, gardens) and falling from bicycle. When evaluated by age groups and fall types the highest prevalence are as follows:: in babyhood inhouse simple falls place on the top (83\%), in school age out-home simple falls $(47 \%)[9,10]$. Wong et al [11] showed that the physicians with higher fear of malpractice will be more likely to order head BT scans for the minor head trauma. When the patients in our study were evaluated by trauma type, the admission rates associated with simple fall, falling from higher places and falling from stairs were higher in PECARN $(+)$ group, but all of the patients in PECARN (-) group were admitted due to simple falls. The difference between these 2 groups was that the highly energetic trauma histories including falling from high places and stairs are CCT indications according to the PECARN rules. The issue to be discussed is that the reasons of CCT in the patients admitted for simple falls in the PECARN (-) group. We think the most important reason is the insistence of the family. Besides, the physicians with higher fear of malpractice, the crowded patient population of the emergency rooms, the increased numbers and the availability of the tomography devices in the recent years will lead to order more CCT scans.

American Pediatric Academy (APA) defined the "minor head trauma" as the head traumas without the signs of skull fracture including 'Battle sign', hemotympanum in physical examination, without the abnormalities in the neurological and fundus examination in the 2-20 years old cases with normal mental level in the first examination. The other parameters in these groups include transient loss of consciousness less than 1 minute, vomiting immediately after the trauma, head ache, lethargy and seizures [1]. Turedi et al [12] similarly declared that the cases with minor head trauma could be discharged safely without CCT in the low-risk GCS 15 group. In our study, the most common symptoms requiring $\mathrm{CCT}$ in the children below and above 2 years old in PECARN $(+)$ group were scalp swelling, scalp hematoma and vomiting. In PE- 
CARN (-) group without the signs of PECARN rules (scalp swelling, scalp hematoma, vomiting, headache and amnesia), the most common signs were varisized cuts in the scalp and dermal abrasions. Approximately $25 \%$ of the patients did not have any of the mentioned signs, but they had undergone CCT. We think that the reasons of the CCT in these patients were the insistence of the families, the physicians with higher fear of malpractice, the difficulty of diagnosis associated with the crowded patient population in the emergency rooms, the need of rapid and accurate diagnosis without the risk of misdiagnosis.

Mannix et al [13] showed in their studies that $6 \%$ of the patients with minor head trauma had pathological CCT results. Since these patients did not require any surgical procedures, they had been discharged without any treatments. Therefore, it is suggested that the lowrisk patients might be discharged safely without the requirement of CCT. Servadei et al [14] classified the minor head trauma as low-, moderate- and high-risk groups. According to this classification, if GCS is 15, and there is no transient loss of consciousness, vomiting, amnesia, common head ache, these patients are in low-risk group and their intracranial bleeding risk requiring surgery is $0.2 \%$. They suggested that these patients should be discharged without the requirement of CCT. In our study, the incidence of fracture in CCT was significantly higher in PECARN $(+)$ group as compared to PECARN (-) group. Although there were 3 patients with fractures in PECARN (-) group, since these patients did not require intensive care and their hospitalization period was shorter than 48 hours, we appreciate the importance and value of PECARN rules. This study showed that CCT according to PECARN rules prevents unnecessary CCT in most of the cases. These results are in line with the literature.

The larger part, approximately $75 \%$, of the patients in our study was the patients requiring CCT according to PECARN rules. The remaining 25\% patients did not require CCT according to PECARN rules. Although there were 3 patients with fractures in these groups, these fractures were not clinically important and did not prolong the hospitalization period, therefore may provide important evidence for the feasibility of PECARN rules. PECARN negativity is a valuable criteria preventing unnecessary CCT. If there is scalp swelling and scalp hematoma in the children above and below 2 years old, the possibility of various pathological findings in CCT is increased.
In conclusion, because $\mathrm{CCT}$ poses serious radiation exposure, neurological examination and clinical follow-up should be preferred in the evaluation and observation of the children with minor head trauma. However, selected cases with severe head trauma should be evaluated with CCT.

Declaration of Conflicting Interests: The authors declare that they have no conflict of interest.

Financial Disclosure: No financial support was received.

\section{REFERENCES}

1. Schutzman SA, Barnes P, Duhaime AC, et al. Evaluation and management of children younger than two years old with apparently minor head trauma: proposed guidelines. Pediatrics 2001;107:983993.

2. Jan MMS, Camfield PR, Gordon K, et al. Vomiting after mild head injury is related to migraine. J Pediatr 1997;130:130-135.

3. Andres BT: Management of delayed posttraumatic intracerebral hemorrhage. In: Contemporary Neurosurgery. Tindall GT. Wlliams and Wilkins. Baltimore 1988 .

4. Rosman NP. Acute Head Trauma. In McMillan JA, Feigin RD, DeAngelis C, Jones MD (Eds). Oski’s Pediatrics, Principles \& Practices. Fourth Edition. Lippincott Williams \& Wilkins, Philadelphia 2006;730-746.

5. McLaurin RL, Towbin R. Diagnosis and treatment of head injury in infants and children. In: Youmans JR ed. Neurological Surgery. 3rd ed. Philadelphia: W.B. Saunders Co 1990;2149-2193.

6. Brenner D, Elliston C, Hall E, Berdon W: Estimated risks of radiation-induced fatal cancer from pediatric CT. AJR Am J Roentgenol 2001;176:289-296,

7. Kuppermann N, Holmes JF, Dayan PS, et al. Pediatric Emergency Care Applied Research Network (PECARN). Identification of children at very low risk of clinically-important brain injuries after head trauma: a prospective cohort study. Lancet 2009;3;374:11601170 .

8. Haydel MJ, Preston CA, Mills TJ, et al. Indications for computed tomography in patients with minor head injury. $\mathrm{N}$ Engl J Med 2000;343:100-105.

9. Simşek O, Hiçdönmez T, Hamamcıoğlu MK, et al. Pediatric head injuries: a retrospective analysis of 280 patients. Ulus Travma Derg 2005; $11: 310-317$.

10. Verma S, Lal N, Lodha R, Murmu L. Childhood trauma profile at a tertiary care hospital in India. Indian Pediatr 2009;46:168-171.

11. Wong AC, KowalenkoT, Roahen-Harrison S, et al. A Survey of emergency physicians' fear of malpractice and its association with the decision to order computed tomography scans for children with minor head trauma. Pediatr Emerg Care 2011;27:182-185.

12. Turedi S, Hasanbasoglu A, Gunduz A, Yandi M. Clinical decision instruments for CT scan in minor head trauma. J Emerg Med 2008;34:253-259.

13. Mannix R, Meehan WP, Monuteaux MC, Bachur RG. Computed tomography for minor head injury: Variation and trends in major United States pediatric emergency departments. J Pediatr 2012;160:136-139.

14. Servadei F, Teasdale G, Merry G. Neurotraumatology Committee of the World Federation of Neurosurgical Societies. Defining acute mild head injury in adults: a proposal based on prognostic factors, diagnosis and management. J Neurotrauma 2001;18:657-664. 